\title{
CORAL SNAKE VENOMS: MODE OF ACTION AND PATHOPHYSIOLOGY OF EXPERIMENTAL ENVENOMATION (1)
}

\author{
Oswaldo VITAL BRAZIL (2)
}

\section{S U M M A R Y}

Coral snakes, the New World Elapidae, are included in the genera Micruroides and Micrurus. The genus Micrurus comprises nearly all coral snake species and those which are responsible for human snake-bite accidents. The following generalizations concerning the effects induced by their venoms, and their venom-properties can be made. Coral snake venoms are neurotoxic, producing loss of muscle strenght and death by respiratory paralysis. Local edema and necrosis are not induced nor blood coagulation or hemorrhages. Proteolysis activity is absent or of very low grade. They display phospholipase $A_{2}$ activity. Nephrotoxic effects are not evoked.

The main toxins from elapid venoms are postsynaptic and presynaptic neurotoxins and cardiotoxins. Phospholipases $A_{2}$ endowed with myonecrotic or cardiotoxin-like properties are important toxic components from some elapid venoms.

The mode of action of Micrurus frontalis, $\mathbf{M}$. lemniscatus, $\mathbf{M}$. corallinus and $\mathbf{M}$. fulvius venoms has been investigated in isolated muscle preparations and is here discussed. It is shown that while $\mathbf{M}$. frontalis and $\mathbf{M}$. lemniscatus venoms must contain only neurotoxins that act at the cholinergic end-plate receptor (postsynaptic neurotoxins), M. corallinus venom also inhibits evoked acetylcholine release by the motor nerve endings (presynaptic neurotoxin-like effect) and $\mathbf{M}$ fulvius induces muscle fiber membrane depolarization (cardiotoxin-like effect). The effects produced by $M$. corallinus and $M$. fulvius venoms in vivo in dogs and $M$. frontalis venom in dogs and monkeys are also reported.

KEY WORDS: Coral snake venoms; Neuromuscular junction; Postsynaptic action; Presynaptic action; Cardiotoxin-like action; Neostigmine antagonistic effect.

\section{NTRODUCTION}

Coral snakes are the Elapidae of the New World. Contrary to the main representatives of this family in Asia, Africa and Australia, they are burroing, timid, low agressive snakes. This explains why accidents caused by them are so infrequent. Actually they generally occur when an incautious person handles one of these beautiful snakes thinking they are nonvenomous and inoffensive, a confusion with some coral snakelike serpents (false coral snakes belonging to the family Colubridae). Coral snakes are included in two genera, Micruroides and Micrurus. Micruroides is known from southwestern United Sta tes and western Mexico. There is only one species of Micruroides, Micruroides euryxanthus, of which three subspecies are recognized. The

(1) Iecture delivered at the South African Institute Ior Medical Research, Johannesburg, South Africa, in August 3rd. 1983.

(3) Department of Pharmacology, Faculty of Medical Sciences, State University of Campinas, P.O. Box 6.111. 13.100 Campinas - SP., Brazil. 
VITAL BRAZIL, O. - Coral snake venoms: mode of action and pathophysiology of experimental envenomation. Rev. Inst. Med. trop. Sāo Paulo, 29:119.126, 1987.

species and subspecies of Micrurus, on the contrary, are very numerous, about 120 according to Roze 11. They are distributed throughout the tropical and warm-temperate parts of North, Central and South America. However, the mode of action of the venom of only a few species has been submitted to investigation. They are the venom of $M$. fulvius, $M$. frontalis, $M$. corallinus and $M$. lemniscatus, the first from United States and Mexico, the others from South America. Nevertheless, the following generalizations concerning the effects induced by their venoms, and venom-properties can be made (BRAZIL 2; ROSENFELD 10; SHAW 12). Coral snake venoms are neurotoxic, producing loss of muscle strenght and death by respiratory paralysis. Eyelid ptosis, ophthalmoplegia, paralysis of jaw muscle, larynx and pharynx, besides sialorrhea and paralysis of neck and limb muscles are observed in the poisoning produced by coral snake venoms. Local edema and necrosis are not induced. They do not cause also blood coagulation or hemorragies. Proteolysis activity in substracts such as gelatin, casein or fibrin is absent or of low grade. Coral snake venoms have phospholipase $A_{2}$ activity, producing in vitro indirect hemolysis. However, in vivo they do not cause intravascular hemolysis, and hemoglobinuria does not occur in coral snake venom-induced poisoning. Nephrotoxic effects are not evok. ed in animal or human envenomation.

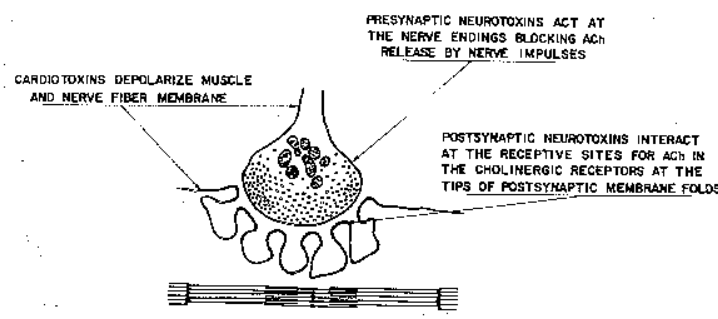

Fig. 1 - Local of action of the elapld neurotoxins and cardiotoxins. Diagram of a neuromuscular junction. In the axoplasm of the nerve terminal, synaptic vesicles (which contain acetylcholine), and mitochondria are represented. At the crests of the folds of the muscle fiber membrane, the acetylcholine receptors are represented by very small black circles.

The main toxins from elapid venoms are postsynaptic neurotoxins, presynaptic neurotoxins and cardiotoxins (LEE 7). Phospholipase $\mathrm{A}_{2}$ endowed with myonecrotic (FOHMAN \& EAKER 4) or cardiotoxin.like (LEE et al ${ }^{8}$ ) properties are other important toxic components from some elapid venoms. Postsynaptic neurotoxins consist of a peptide chain containing 60: to 62 aminoacids and four disulfide bridges (short neurotoxins) or 71 to 74 aminoacids and five dissulfide bridges (KARLSSON 6 ). They are low molecular weight basic proteins with isoeletric points in the vecinity of pH9-10. Postsynaptic neurotoxins interaet with the end-plate cholinergic receptors, causing a slowly reversible or an irreversible neuromuscular blockade (Fig. 1). As curare they are acetylcholine antagonists at the end-plate nicotinic receptor. Postsynaptic neurotoxins has been found to occur in all Elapidae and Hydrophíinae venoms so far investigated. Presynaptic neurotoxins are proteins larger than the postsynaptic neurotoxins. Some are complex of two or three subunits not covalently linked. All display a week phospholipase $A_{2}$ activity which seems to be indispensable for their action. Their primary action is on the motor nerve endings (Fig. 1), inhibiting acetylcholine release produced by nerve impulses and increasing spontaneous acetylcholine release. They may exert also a myotoxic action and, at least in one case (crotoxin), transform the receptor protein from the state of low affinity for agonists to one of high affinity, that is, to induce receptor desensitization (BON et al ${ }^{1}$ ). Presynaptic neurotoxins are the most toxic components of snake venoms. They occur in some elapine venoms and also in those of a few crotaline (HAWGOOD ${ }^{5}$ ). Cardiotoxins, also called direct lytic factor, cobramines, cytotoxins or membrane toxins, are as the postsynaptic neurotoxins, basic polypeptide toxins of low molecular weight (about 6000 to 7000 daltons). They cause depolarization and disruption of the membrane of excitable and non excitable cells. Arrhytmias and cardiovascular depression are also evoked by them. Their potency is much lower than that of postsymaptic neuro. toxins. They ocur in cobra venoms.

The studies so far carried out show that coral snake venoms interact with end-plate re ceptor like the postsynaptic neurotoxins. They show also that they may contain components acting like the presynaptic neurotoxins or the cardiotoxins.

CORAL SNAKE VENOMS EXERTING ONLY POSTSYNAPTIC NEUROTOXIN-LIKE ACTION: MICRURUS FRONTAIIS AND M. LEMNISCA. TUS VENOM. 
VITAL BRAZIL, O. - Coral snake venoms: mode of action and pathophysiology of experimental envenomation. Hev.

Inst. Med. trop. São Paulo, 29:119-126, 1987.

M. frontalis is distributed over centraleastern (Minas Gerais, São Paulo), centralwestern (Southeastern Mato Grosso) and southern Brazil. It is also found in Uruguay, northeastern and northwestern Argentine, Paraguay and Santa Cruz in Boolivia. It comprises seven subspecies (ROZE 11).

M. frontalis venom from snakes captured in the State of São Paulo induces a reversible neuromuscular blockade in the isolated rat phrenic nerve-diaphragm preparation while the blockade elicited by the venom of snakes from southeastern Mato Grosso is irreversible in that preparation (VITAL BRAZIL et al. 17). Evoked acetylcholine release at the phrenic nerve-diaphragm preparation is rather increased by the venom, an effect also produced by alpha-bunga. rotoxin (MILEDI et al. ${ }^{9}$ ) and whose mechanism is not well understood. In the chronically denervated rat hemidiaphragm, $M$. frontalis venom causes an irreversible inhibition of the contracture induced by acetylcholine. D-tubocurarine protects the denervated hemidiaphragm from the venom action (Fig. 2). D-tubocurarine and $M$ frontalis venom act therefore at the same site in the cholinergic receptor. In the toad sartorius, the resting membrane potential and the miniature end-plate potential (m.e.p.p.) frequency are not altered by the venom. M.e.p.ps. are rapidly depressed. All these results show that $\mathbf{M}$. frontalis venom must contain postsynaptic neurotoxin(s), being devoid of

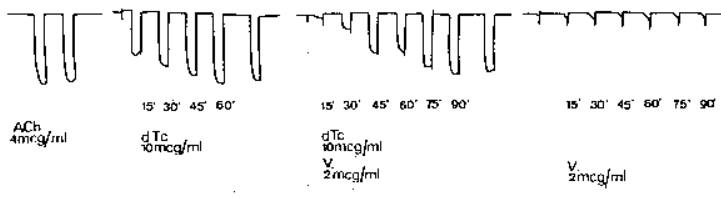

Fig. 2 - Protection by d-tubocurarine (dTc) of the cholinergic receptors from the action of Micrurus frontalis venom ( $V$ ) in the isolated and chronically denervated rat hemidiaphragm. Contractures of the denervated muscle were produced by acetylcholine bromide (ACh) $2 \mathrm{ug} / \mathrm{ml}$. 1. Two responses to ACh before dTc addition to the bath. 2. Addition of $\mathrm{dTc} 10 \mathrm{ug} / \mathrm{ml}$ to the bath; after $30 \mathrm{~min}$ the response to ACh was blocked; upon washing of the preparation the ACh-induced contractures gradually retumed and after $60 \mathrm{~min}$ they were completely recovered. 3. Addition of dTc $10 \mathrm{ug} / \mathrm{ml}$ and after $30 \mathrm{~min}, \mathrm{~V} 2 \mathrm{ug} / \mathrm{ml}$ to the bath; 30 min after $V$ addition and 60 min after dTc add. tín, washing of the preparation was started; complete recovery of $A C h$ responses occured 90 min aftar the washing start. 4. Addition of $\mathrm{V} 2 \mathrm{ug} / \mathrm{ml}$ to the bath; wushing of the preparation for $90 \mathrm{~min}$ had no effect on the depresston produced by $\mathbf{V}$ of the ACh-induced responses. (From ref. 17). presynaptic neurotoxins and of depolarizing components.

M. frontalis venom when injected i.v. in anesthetized dogs produces an abrupt fall of blood pressure which can be lethal to the animals (VITAL BRAZIL et al. 17). However, when injected intramusculary, the effect on blood pressure is always mild and the dogs die from respiratory paralysis. After cessation of spontaneous respiration, the animals can be mantained alive under artificial respiration. The respiratory paralysis is peripheral in origin. This was proven by recording discharges of action potentials in the phrenic nerve after cessation of spontaneous respiration in dogs supported by artificial respiration (Fig. 3). In the dog scia. tic nerve-tibialis anterior muscle preparation in situ, the neuromuscular blockade produ. ced by the venom is antagonized by neostig. mine (VITAL BRAZIL et al. ${ }^{17}$ ). The same occurs in the rat sciatic nerve-gastrocnemius muscle preparation in situ (VITAL BRAZIL \& BAR RIO ${ }^{15}$ ). Neostigmine also antagonizes the respiratory paralysis induced by the venom. This was documented by recording the electromyogram of diaphragms of dogs injected with $\mathbf{M}$. frontalis venom (Fig. 4). The effectiveness of neostigmine in counteracting the paralysis and preventing death produced by $M$. frontalis venom was also proven in unanesthetized monkeys (Fig. 5) and dogs (Table I).

M. lemniscatus distribution is very large. It is found in the Guyanas, Trinidad, Venezuela, Colombia, Equador, Bolivia and in northern, northeastern and central Brazil until Parana and Mato Grosso. It comprises four subspecies (ROZE 11).

M. lemniscatus venom elicits a reversible neuromuscular blockade in the rat phrenic nerve-diaphragm preparation (VITAL BRAZIL 14). In the chronically denervated rat hemidiaphragm, it inhibits the contracture induced by acetylcholine (Fig. 6) and other cholinergic agonists. It does not depress the contracture produced in that preparation by potassium ions. The amplitude of the responses induced by direct mus cle stimulation is not reduced in the innervated diaphragm by the venom. Its effects on acetyl. choline release was not investigated However, since the action of all presynaptic neurotoxins 
VITAL BRAZIL, O. - Coral snake venoms: mode of action and pathophysiology of experimental envenomation. Rer. Inst. Med. trop. São Paulo, 29:119-126, 1987.

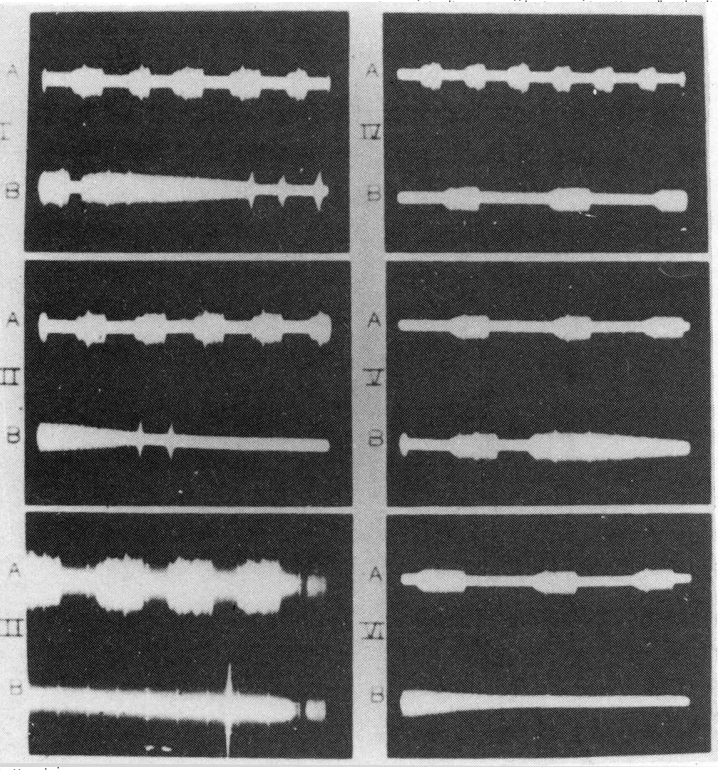

Fig. 3 - Peripheral origin of the respiratory paralysis induced by Milcrurus frontalis venom. Discharges of action potentials recorded in central slip of a phrenic nerve root of a dog injected with $M$. frontalis venom $(0.7 \mathrm{mg} / \mathrm{kg} \mathrm{i} . \mathrm{m}$.) about $3 \mathrm{~h} 20 \mathrm{~min}$ before the experiment. The dog sponteneous respiration stoped 1 hour before. I A, II A, III A, IV $A$ and $B, V$ A and VI A, discharges of action potentials recorded during artificial respiration. I B, II B, III B, $V B$ and $V I B$ records of the bioelectrical activity in the phrenic nerve after stopping artlficial respiration respectively for $0.5,1.0,2.0,1.0$ and $2.0 \mathrm{~min}$. IV $\mathrm{B}, \mathrm{V}$ and $\mathrm{VI}$ discharges of action potentials were recorded after section of both vagd (observe in IV B, V A and VI A that the discharges did not accompany any more the rhythm of the artificial respiration). (From ref. 17).

is irreversible, it seems that M. lemniscatus yenom induces neuromuscular blockade by inte racting only with the end plate cholinergic receptors.

\section{CORAL SNAKE VENOMS EXERTING} POSTSYNAPTIC NEUROTOXIN-LIKE AND PRESYNAPTIC NEUROTOXIN-LIKE ACTIONS: MICRURUS CORAMLINS VENOM.

M. corallinus is distributed over central and southern Brazil, south of Amazon Basin and northern Argentine; it occurs probably also in Uruguay according to ROZE "1). Its venom induces an irreversible neuromuscular blockade in the rat phrenic nerve-diaphragm preparation (VITAL BRAZIL \& FONTANA ${ }^{16)}$. Spontaneous acetylcholine release is increased by $M$. corallinus venom while the evoked one is inhibited (Tr. ble II). The venom increases m.e.p.p. frequency before depressing the amplitude of these
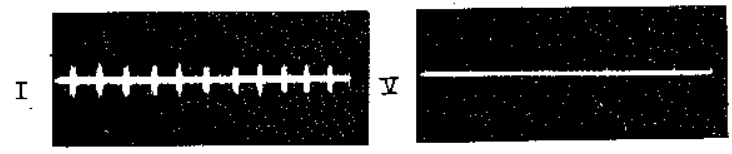

II
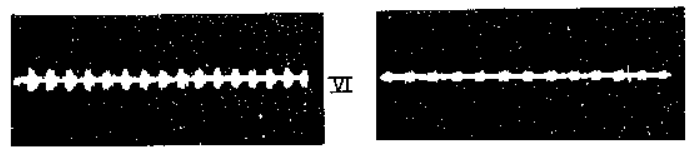

III
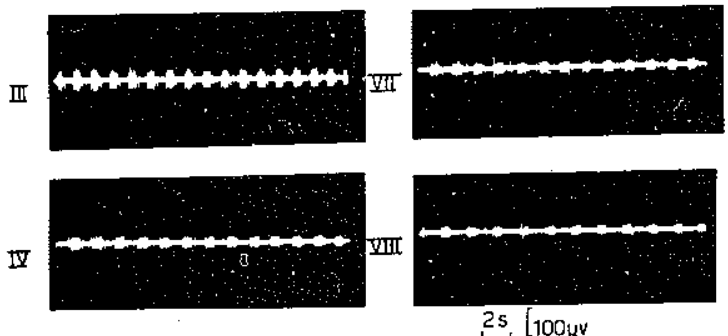

Fig. 4 - Antagonistic effect of neostigmine on the respiratory paralysis induced by Milcrurus frontalis venom. Electromyogram of the disphragm of a dog injected i.m. with $0.85 \mathrm{mg} / \mathrm{kg}$ of venom. 1 . Electromyogram before venom injection. II. III, IV and V, electromyograms 110, 135, 200 and $240 \mathrm{~min}$ after venom injection. VI, VII and VIII, electromyograms after injection i.v. of $0.1 \mathrm{mg} / \mathrm{kg}$ of methylsulfate of neostigmine. Neostigmine was injected \& min after spontaneous respiration arrest (V). (From ref. 17).

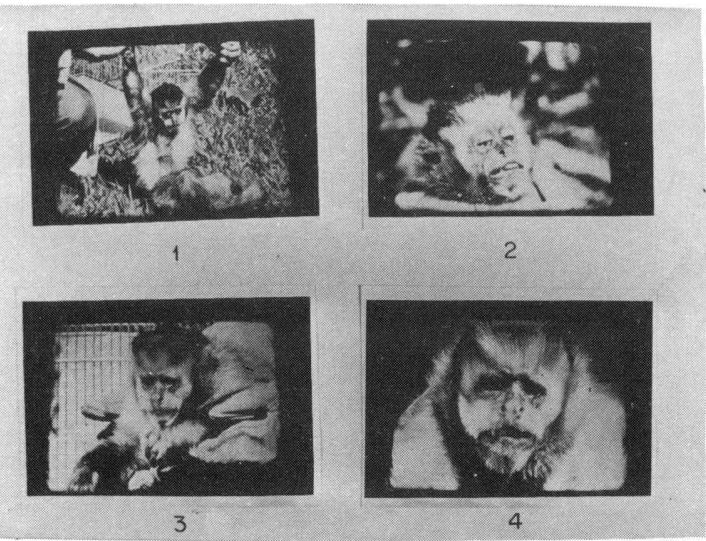

Fig. 5 - Antagonistic effect of neostigmine on the paralysis induced by Mijcrurus frontalis venom in unanesthetived monkeys (Cebus sp). 1 and 2: Photographs of a monkey about $3 \mathrm{~h}$ after the injection $\mathrm{i} . \mathrm{m}$. of $0.5 \mathrm{mg} / \mathrm{kg}$ and $2 \mathrm{~h}$ after $\mathrm{s}$ second injection $0.4 \mathrm{mg} / \mathrm{kg}$. The photographs show that the monkey. has completely lost its muscle strenght and presents eye-lid and mandibular ptosis. 3 and 4 : Pho tographs 5 and $10 \mathrm{~min}$ after the injection 1.v. of 0.05 $\mathrm{mg} / \mathrm{kg}$ of methylsulfate of neostigmine. The photographs show that all motor signs of $M$. frontalls venom polsoning have disappeared. The injection of neostigrnine was made Immediately after the photographs I and II were taken (from the film). The antagonistic effect produced by neostigmine upon the paralysis calused by Micrurus frontalls venom, directed by Vital Brazil, O. \& Pellegrini Filho, A. See Rosenberg, P. (Ed.) Toxins Animal, Plant and Microblal, Oxford, Pergamon Press, 1978, pp. 437-438). 
VITAL BRAZJL, O. - Coral snake venoms: mode of action and pathophysiology of experimental envenomation. Rev. lnst. Med. trop. 'Sāo Paulo, 29:119-126, 1987.

T A B L E I

Treatment with neostigmine (neostigmine methylsulfate) of experimental poisoning induced by Micrurus frontalls venom in dogs

\begin{tabular}{|c|c|c|c|c|c|}
\hline $\begin{array}{l}\text { Exp. } \\
\text { n.0 }\end{array}$ & $\begin{array}{c}\text { Dog } \\
\text { (weight) }\end{array}$ & $\begin{array}{l}\text { Venom (0.95 mg, } \\
\text { i.m.) injection } \\
\text { (hour) }\end{array}$ & $\begin{array}{l}\text { Respiratory depres- } \\
\text { ision (hour) } \\
.\end{array}$ & $\begin{array}{l}\text { Nepstigmine }(0.05 \mathrm{mg} / \\
\mathrm{kg} \text { i.v.) injection } \\
\text { (hour) }\end{array}$ & Resuit \\
\hline 1 & $\begin{array}{l}4.9 \mathrm{~kg} \\
4.0 \mathrm{~kg}\end{array}$ & $\begin{array}{l}9 \text { h } 55 \mathrm{~min} \text { a.m. } \\
9 \mathrm{~h} 50 \mathrm{~min} \text { a.m. }\end{array}$ & $\begin{array}{l}\text { il h a.m. } \\
11 \text { h a.m. }\end{array}$ & $\begin{array}{c}11 \mathrm{~h} 55 \mathrm{~min} \text { a.m. } \\
-\end{array}$ & $\begin{array}{l}\text { Survived } \\
\text { Dead at } 11 \text { h } 50 \text { min a.m. }\end{array}$ \\
\hline $\mathbf{2}$ & $\begin{array}{l}6.3 \mathrm{~kg} \\
5.8 \mathrm{~kg}\end{array}$ & $\begin{array}{l}11 \text { h } 50 \mathrm{~min} \text { a.m. } \\
11 \mathrm{~h} 30 \mathrm{~min} \text { a.m. }\end{array}$ & $\begin{array}{l}1 \mathrm{~h} \quad 20 \mathrm{~min} \mathrm{pm} . \\
12 \mathrm{~h} 50 \mathrm{~min} \text { noon }\end{array}$ & $\begin{array}{cccc}1 & h & 30 & \text { min a.m. } \\
& & \\
& & \end{array}$ & $\begin{array}{l}\text { Survived } \\
\text { Dead at } 1 \mathrm{~h} 20 \mathrm{~min} \text { p.m. }\end{array}$ \\
\hline 3 & $\begin{array}{l}7.7 \mathrm{~kg} \\
6.4 \mathrm{~kg}\end{array}$ & $\begin{array}{l}9 \text { h } 40 \text { min a.m. } \\
9 \text { h } 25 \text { min a.m. }\end{array}$ & $\begin{array}{l}10 \text { h } 30 \mathrm{~min} \text { a.m. } \\
11 \text { h a.m. }\end{array}$ & $\begin{array}{c}10 \text { b } 40 \mathrm{~min} \text { a.m. } \\
-\end{array}$ & $\begin{array}{l}\text { Survived } \\
\text { Dead at } 11 \text { h } 20 \text { min a.m. }\end{array}$ \\
\hline 4 & $\begin{array}{l}5.8 \mathrm{~kg} \\
5.3 \mathrm{~kg}\end{array}$ & $\begin{array}{l}12 \text { h } 5 \text { min noon } \\
12 \text { h } 10 \text { min noon }\end{array}$ & $\begin{array}{llll}2 & \text { h } & \text { p.m. } \\
2 & \text { h } & \text { p.m. }\end{array}$ & $\begin{array}{c}14 \text { h } 5 \text { min p.m.** } \\
\\
\end{array}$ & $\begin{array}{l}\text { Survived } \\
\text { Dead at } 2 \mathrm{~h} 30 . \mathrm{min} \text { p.m. }\end{array}$ \\
\hline 5 & $\begin{array}{l}5.4 \mathrm{~kg} \\
4.8 \mathrm{~kg}\end{array}$ & $\begin{array}{l}10 \mathrm{~h} \text { a.m. } \\
10 \mathrm{~h} 5 \mathrm{~min} \text { a.m. }\end{array}$ & $\begin{array}{l}11 \text { h } 55 \mathrm{~min} \text { a.m. } \\
12 \text { h } 10 \mathrm{~min} \text { noon }\end{array}$ & $\begin{array}{ccc}12 & h & 15 \\
& \\
& \end{array}$ & $\begin{array}{l}\text { Survived } \\
\text { Dead at } 1 \mathrm{~h} \text { p.m. }\end{array}$ \\
\hline
\end{tabular}

* A second injection of neastigmine was made after $45 \mathrm{~min}$

-* A second injection of neostigmine was made after $20 \mathrm{~min}$

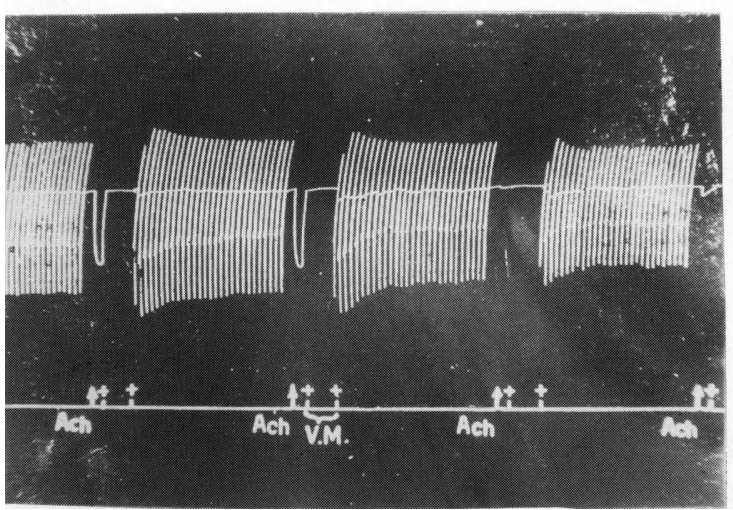

Fig. 6 - Antagonistic effect of Micrurus lemniscatus on the acethylcholine-induced contracture in the isolated and chronically denervated rat hemidiaphragm. The denervated hemidiaphräm was stimulated by electrical pulses $10.1 \overrightarrow{\mathrm{H}}$, $40 \mathrm{~V}, 2 \mathrm{~ms}$ ) and acethylcholine iodide $(4 \mathrm{ug} / \mathrm{ml})$. The venom was added to the bath $30 \mathrm{~min}$ before the start of electrical stimulation and $35 \mathrm{~min}$ before $\mathrm{ACh}$ addition to the bath. (From ref. 14).

potentials (Fig. 7). The resting membrane potential and excitability of the rat diaphragm are not altered by $\boldsymbol{M}$. corrallinus venom. In the isolated and chronically denervated rat hemidiaphragm, the venom reversibly blocks acetylcholine-induced contracture (Fig. 8). These results show that $M$. corallinus venom must contain postsynaptic and presynaptic neuroto-

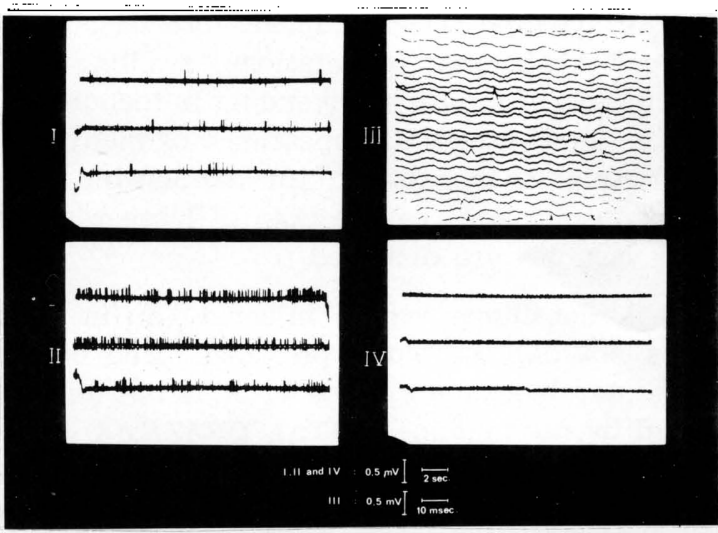

Fig. 7 - Effects of Micrurus corallinus venom on miniature endplate potentials (m.e.p.ps.). I M.e.p.ps. before venom addition to the bath. II, III and IV M.e.p.ps. 20, 40 and $60 \mathrm{~min}$ after the addition of $5 \mathrm{ug} / \mathrm{ml}$ of venom to the bath (From ref. 16).

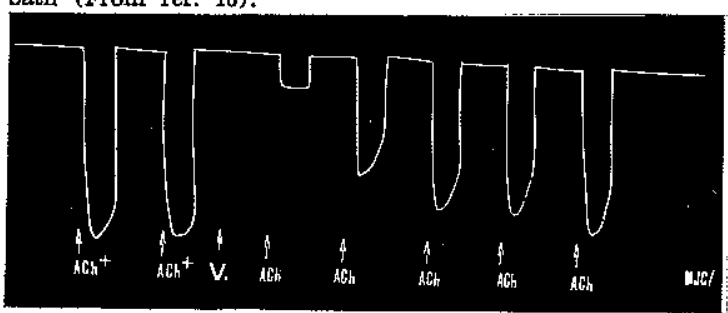

Fig. 8 - Antagonistic effect of Micrurus corallinus venom on the acetyicholine induced contracture in the isolated and chronically denerrated rat hemidiaphragm. Acetylcholine iodide $(\mathrm{ACh}), 4 \mathrm{ug} / \mathrm{ml}$; venom, $2 \mathrm{ug} / \mathrm{ml}$. The ras ponses to ACh gradually returned on washing the prepara tion. (From ref. 16). 
VITAL BRAZIL, O. - Coral snake venoms: mode of action and pathophysiology of experimental envenomation. Rev. Inst. Med. trop. São Paulo, 29:119-126, 1987.

T A B I, E II

Effect of Micrurus corallinus venom on acetylcholine (ACh) release (in nanograms). Rat phrenic nerve-diaphragm preparations

\begin{tabular}{|c|c|c|c|c|}
\hline \multirow[t]{2}{*}{ Exps. } & \multicolumn{2}{|c|}{$\begin{array}{l}\text { ACh release before venom } \\
\text { addition to the bath }\end{array}$} & \multicolumn{2}{|c|}{$\begin{array}{c}\text { ACh release after neuromuscular } \\
\text { blockade induced by } 10 \mathrm{ug} / \mathrm{ml} \text { of } \\
\text { venom }\end{array}$} \\
\hline & $\begin{array}{l}\text { Spontaneous } \\
\text { release }\end{array}$ & $\begin{array}{l}\text { Release by } \\
\text { nerve impulses }\end{array}$ & $\begin{array}{l}\text { Spontaneous } \\
\text { release }\end{array}$ & $\begin{array}{l}\text { Release by } \\
\text { nerve impulses }\end{array}$ \\
\hline 1 & 6.4 & 55.6 & 9.1 & 21.1 \\
\hline 2 & 8.4 & 64.8 & 14.0 & 28.0 \\
\hline 3 & 8.5 & 49.0 & 15.0 & 30.0 \\
\hline Mean \pm & & & & \\
\hline S.E.M. & $7.7 \pm 0.9$ & $56.4 \pm 0.9$ & $12.7 \pm 2.5$ & $26.4 \pm 3.8$ \\
\hline
\end{tabular}

xins and that it is devoid of myotoxic components.

The ultrastructure changes caused by $\mathbf{M}$ corallinus venom were investigated in the mouse phrenic nerve-diaphragm preparation (CRUZ HöFLING et al. ${ }^{3)}$. They were found to be similar to those produced by the presynaptic neurotoxin beta-bungarotoxin: reduction in number of synaptic vesicles, appearance of omegashaped axolemmal indentations, swelling and disruption of motor nerve ending mitochondria. At the latest stages disappearance of many nerve terminals, increase in the axoplasmic electron opacity and the presence of large vesicles and vacuoles are observed.

M. corallinus venom injected i.m. in dogs does not depress blood pressure. The neuromuscular blockade elicited by it is not antagonized by neostigmine (VITAL BRAZIL \& FONTANA 16). This suggests that in the dog the main cause of the neuromuscular blockade is presynaptic in origin.

CORAL SNAKE VENOMS EXERTING POSTSYNAPTIC NEUROTOXIN-LIKE ACTION AND INDUCING DEPOLARIZATION OF MUSCLE FIBER MEMBRANE: MICRURUS FUL VIUS VENOM.

M. fulvius is distributed over southeastern North Caroline to the tip of Florida, the Gulf coastal plain to the Mississippi River and, west of it, Louisiana. Arkansas and Texas in United States, and northeastern Mexico. It comprises five subspecies (ROZE 11).

M. fulvius venom was investigated by WEISS 2 McISAAC 18 in anesthetized cats, isolated rat muscle preparations and frog rectus abdominis muscle. The venom slowly infused i.v. in cats evokes a rapid and temporary fall of blood pressure. Neuromuscular and respiratory depression are manifest after one hour. After complete neuromuscular blockade, the muscle (tibialis an. terior) responds to direct stimulation for about one hour. Artificial respiration after cessation of spontaneous respiration maintains the cats alive for some time (bteween 2.5 and 9.5 hours after the start of venom injection) but they finally die presumably from hypotension. In isolated rat muscle preparations the venom produces neuromuscular blockade and also depression of the responses to direct muscle stimulation. The neuromuscular blockade was not antagonized by neostigmine or edrophonium, and prolonged washing of the preparation causes only less than a 10 per cent recovery. $M$. fulvius venom induces depolarization of the muscle fiber membrane and cause muscle fiber swelling and hyaline degeneration. A small reduction, not dose-dependent, is produced by the venom in the responses of the frog rectus abdominis to acetylcholine. WEISS \& MCISAAK 18 conclude from the results of their research that $M$. fulvius venom acts in a fashion analogous in some respects to the cardiotoxin from cobra venom and that it possibly contains a fraction which blocks the acetylcholine receptors. On the other hand, SNYDER and co-wor kers ${ }^{13}$ isolated from $M$. fulvius venom a neuro. toxic fraction which produces neuromuscular blockade in chick biventer cervicis nerve-mus. cle preparation and inhibits the acetylcholineinduced contracture in this preparation in dose-dependent manner. It does not show the depolarizing activity of the crude venom. The action of the fraction is irreversible. 
VTTAL BRAZIL, O. - Coral snake venoms: mode of action and pathophysiology of experimental envenomation. Rev. Inst. Med. trop. São Paulo, 29:119-126, 1987.

\section{RESUMO}

Peçonhas de cobras corais: modo de ação e fisiopatologia do envenenamento experimental.

As cobras corais são os representantes da família Elapidae nas Américas. Classificam-se em dois gêneros Micruroides e Micrurus. $O$ gênero Micrurus compreende a quase totalidade das espécies de cobra coral e todas as que causam acidentes no homem. Podem-se fazer as seguintes generalizaçōes quanto aos efeitos produzidos por suas peçonhas e a algumas propriedades destas. As peçonhas das cobras corais são neurotóxicas, causando perda da força muscular e morte por paralisia respiratória. Não provocam edema local e necrose assim como não produzem coagulação sanguínea ou hemorragias. A atividade proteolítica das peçonhas de cobras corais é pequena ou nula. Exercem atividade fosfolipase $A_{2}$. Não induzem efeitos nefrotóxicos.

Os componentes tóxicos da peçonha das Elapidae são as neurotoxinas pré-sinápticas, as neurotoxinas pós-sinåpticas, as cardiotoxinas $\mathrm{e}$ fosfolipases $A_{2}$ com atividade mionecrótica ou semelhante à das cardiotoxinas.

O modo de ação das peçonhas de Micrurus frontalis, $M$. lemniscatus, $M$. corallinus e M. fulvius foi investigado em preparaçōes neuromusculares isoladas e é aqui exposto. Mostra-se que enquanto as peçonhas de $M$. frontalis e $M$. lemniscatus devem conter apenas toxinas que atuam através de ligação com os receptores colinérgicos da placa terminal (neurotoxinas póssinápticas), a de $M$. corallinus atua também na junção neuromuscular inibindo a liberação de acetilcolina pelos impulsos nervosos e a de $\mathbf{M}$. fulvius induz despolarização da membrana das fibras musculares. Relatam-se também os efeitos produzidos pelas peçonhas de $\mathbf{M}$. corallinus e M. fulvius in vivo em cães e os provocados pela peçonha de M. frontalis em cães e macacos.

\section{REFERENCES}

1. BON, C.; ChaNGEUX, J. P.; JENG, T. W. \& FRAENKEL-CONRAT, H. - Postsynaptic effects of crotoxin and of its isolated subunits. Europ. J. Biochem., 99: 471-481, 1979.

2. BRAZIL, V. - La dëfense contre l'ophidisme. 2eme ed. São Paulo, Pocai Weiss, 1914.
3. CRUZ-HöFLING, M. A.; RODRIGUES-SIMIONI, L. \& VITAL BRAZIL, O. - Ultrastructure changes in neuromuscular junctions of the mouse diaphragm caused by the venom of the coral snake Micrurus corallinus. Mem. Inst. Butantan, 47-48: 95-105, 1983/84.

4. FOHHMAN, J. \& EAKER, D. - Isolation and characterization of a lethal myotoxic phospholipase $A$ from venom of the common sea-snake Enhydrina schistoss causing myoglobinuria in mice. Toxicon, 15: 385-393, 1977.

5. HAWGOOD, J. B. - Physiological and pharmacological effects of rattlesnake venoms. In: TU, A. T., ed. - Rattlesnake venoms; their action and treatment. New York, Marcel Dekcker, 1982. p. 121-162.

6. KARLSSON, E. - Chemistry of protein toxins in snake venoms. In: LEE, C. Y., ed. - Snake venoms. Berlin, Springer-Verlag, 1979. p. 159-204.

7. LEE, C. Y. - Chemistry and pharmacology of polypeptide toxin in snake venoms. Ann. Rev. Pharmacol., 12: $265-284,1972$.

B. LEE, C. Y.; HO, C. L. \& EAKER, D. - Cardiotoxinlike action of a basic phospholipase $A$ isolated from Naja nigricollis venom. Toxicon, 15: 355-356, 1977.

9. MILFDI, R.; MOLENAAR, P. C. \& POLAK, R. L. Alpha-bungarotoxin enhances transmitter "released" at the neuromuscular junction. Nature, 272: 641-643, 1978.

10. ROSENFELD, D. - Symptomatology, pathology, and treatment of snake bites in South America. In: BUCHERL, W. \& BUCKLEY, E. E., @d. - Venomous animals and their venoms. New York, Academic Press, 1971. v. 2, p. $345-384$.

11. ROZE, J. A. - New world coral snakes (Elapidae): a taxonomic and biological summary. Mem. Inst. Butantan, 46: 305-338, 1982.

12. SHAW, C. E. - The coral snakes Micrurus and Micruroldes of the United States and Northern Mexico. In: BUCHERL, W. \& BUCKIEY, E. E., ed. - Veno. mous animals and their venoms. New York, Academic Press, 1971. v. 2, p. 157-172.

13. SNYDER, G. K.; RAMSEY, H. W.; TAYLOR, W. J. \& CHIOU, C. Y. - Neuromuscular blockade of chick biventer cervicis nervemuscle preparation by a fraction from coral snake venom. Toxicon, 11: 505-508, 1973.

14. VITAL BRAZIL, O. - Ação neuromuscular da peço. nha de Micrurus. São Paulo, 1963. (Tese de doutoramento - Faculdade de Medicina da Universidade de São Paulo).

15. VITAL BRAZIL, O. \& BARRIO, A. - Acción curarlzante de las ponzoñas de elapidae. II. Fiffectos de algunos antagonistas del curare. Rev. Inst. Malbran. 16: $11-18,1954$.

16. VTTAL BRAzIL, O. \& FONTANA, M. D. - Ações pré-juncionais e pós-juncionais da peçonha da cobra 
VITAL BRAZIL, O. - Coral snake venoms: mode of action and pathophysiology of experimental envenomation. Rev. Inst. Med. trop. Sầ Paulo, 29:119-126, 1987.

coral Micrurus corallinus na junçă neuromuscular. Mem. Inst. Butantan, 47-48: 13-26, 1983/84.

17. VITAL BRAZIL, O.; FONTANA, M. D. \& PEHIEGRINI FTr.HO, A. - Physiologie et therapeutique de l'envenomation expérimental causées par le venin de Mi. crurus frontalls. Mem. Inst. Butantan, 40.41: 21-240, 1976/77.
18. WEISS, R. \& MCISAAC, R. J. - Cardiovascular and musetular effects of venom from coral snake, Micrurus tulvius. Toxlcon, 9: 219-228, 1971.

Recebido para publicagäo em 2/2/87. 